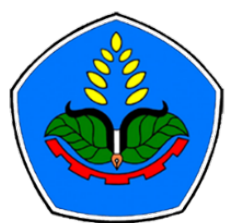

AGROPROSS

National Conference

Proceedings of Agriculture

\section{Proceedings:}

Peningkatan Produktivitas Pertanian Era Society 5.0 Pasca Pandemi

Tempat : Politeknik Negeri Jember

Tanggal : 22 Juli 2021

Publisher :

Agropross, National Conference Proceedings of Agriculture

ISBN : 978-623-94036-6-9

DOI : 10.25047 /agropross.2021.210

\title{
Analisis Peran Air Kelapa Terhadap Pertumbuhan Eksplan Kultur Vanili (Vanilla planifolia)
}

\author{
Author(s): Nur Khofifah Ariyanti ${ }^{(1)}$, Dyah Nuning Erawati ${ }^{(1)^{*}}$, Rahma Sarita $^{(1)}$, Sabilla \\ Jasmine Belinda ${ }^{(1)}$ \\ (1) Jurusan Produksi Pertanian Politeknik Negeri Jember \\ * Corresponding author:dyah_nuning_e@polije.ac.id
}

\begin{abstract}
The prospect of vanilla (Vanilla planifolia) is a commodity that generates foreign exchange for the country is still very likely to be developed. One of the techniques in developing vanilla is through the cultivation of the plant tissue culture method with the addition of coconut water as a source of natural growth regulators so that the explants from the vanilla stem segments can grow and develop optimally. The purpose of this study was to analyze the role of coconut water on the growth of vanilla culture explants. The research was carried out in February - June 2021 at the Tissue Culture Laboratory of Politeknik Negeri Jember. The T-test analysis method was used to compare the treatment without the addition of coconut water (P0) with the addition of $15 \%$ coconut water (P1) on Murashige-Skoog basic media. The results showed that 1) The addition of 15\% coconut water affected the bud height of vanilla explants with an average of $4.45 \mathrm{~cm} /$ explant and the number of roots with an average of 2.03 roots/explants at the age of 56 dai, 2) The addition of $15 \%$ coconut water had an effect on the same as without the addition of coconut water on early buds, the number of roots at 14, 28, 42 dai and root length of vanilla explants, 3) The addition of 15\% coconut water was able to support the growth of shoot and root length but was not able to multiplication the shoots of vanilla explants.
\end{abstract}

Keywords:

coconut water,

culture,

MS medium,

Vanilla.

\section{Kata Kunci: ABSTRAK}

air kelapa,

Prospek vanili (Vanilla planifolia) sebagai komoditas penghasil devisa negara masih sangat berpeluang untuk dikembangkan. Salah satu teknik dalam pengembangan vanili melalui metode

kultur jaringan, budidaya kultur jaringan tanaman dengan penambahan air kelapa sebagai sumber zat pengatur

media MS, tumbuh alami agar eksplan asal ruas batang vanili dapat tumbuh dan berkembang secara optimal. Air kelapa dapat diperoleh dengan mudah sehingga lebih efisien pada segi biaya dan waktu. Oleh karena itu, tujuan dari penelitian ini adalah menganalisis peran air kelapa terhadap pertumbuhan

vanili. eksplan kultur vanili. Pelaksanaan penelitian pada bulan Februari - Juni 2021 di Laboratorium Kultur Jaringan Politeknik Negeri Jember. Metode analisis $\mathrm{T}$ test digunakan untuk membandingkan perlakuan tanpa penambahan air kelapa (P0) dengan perlakuan penambahan air kelapa 15\% (P1) pada media dasar Murashige-Skoog. Hasil penelitian memperlihatkan bahwa 1) Penambahan air kelapa 15\% mempengaruhi tinggi tunas eksplan vanili dengan rerata 4,45 $\mathrm{cm} /$ eksplan dan jumlah akar dengan rerata 2,03 akar/eksplan pada umur eksplan 56 hsi, 2) Penambahan air kelapa $15 \%$ memiliki pengaruh yang sama dengan tanpa penambahan air kelapa terhadap kedinian bertunas, jumlah akar pada 14, 28, 42 hsi dan panjang akar eksplan vanili, 3) Penambahan air kelapa $15 \%$ mampu mendukung pertumbuhan panjang tunas dan akar tetapi tidak mampu menggandakan tunas eksplan vanili. 


\section{PENDAHULUAN}

Tanaman vanili merupakan komoditas penghasil devisa negara sebesar US\$ 63 juta pada tahun 2018 yang masih layak untuk dikembangkan di Indonesia karena nilai ekonomisnya tinggi (Leodji, 2019). Perbanyakan tanaman vanili dapat dilakukan dengan cara generatif dan vegetatif. Perbanyakan secara generatif dapat berasal dari biji dan secara vegetatif secara konvensional dapat dilakukan dengan stek (Kartikawati dan Rosihan, 2018). Perbanyakan dengan stek memiliki kelemahan yaitu rentan terserang jamur Fysarium oxysporum yang menyebabkan penyakit busuk batang yang sulit dikendalikan sehingga dapat mempengaruhi produktivitas (Erona, 2016). Teknik perbanyakan secara in vitro dengan kultur jaringan memiliki kelebihan untuk perbanyakan tanaman secara masal dalam waktu yang relatif singkat dengan sifat baik dari fisiologi dan morfologi sama dengan induknya (Nasution, 2013).

Perbanyakan vanili dengan teknik mikropropagasi seringkali menggunakan zat pengatur tumbuh. ZPT dapat berasal dari tanaman itu sendiri (endogen) dan dapat berasal dari sintetik (eksogen) (Wiraatmaja, 2017). ZPT sintetik yang digunakan untuk perbanyakan tunas vanili berasal dari golongan sitokinin seperti kinetin, BAP atau BA yang berfungsi dalam pembelahan sel (Widiastoety, 2016). Zat pengatur tumbuh tanaman berperan penting dalam mengkontrol proses biologi dalam jaringan tanaman yang akan dikulturkan. Erawati, dkk (2020) melaporkan bahwa stimulasi BAP secara tunggal dapat mempengaruhi multiplikasi tunas vanili dengan rerata jumlah tunas terbanyak 6.8 tunas/ eksplan pada konsentrasi BAP $1 \mathrm{mg} / \mathrm{L}$ dan stimulasi NAA secara tunggal menginduksi pembentukan akar dengan rerata jumlah akar terbanyak 3.0 akar/eksplan pada konsentrasi NAA 0.5 $\mathrm{mg} / \mathrm{L}$.
ZPT sitokinin juga dapat diperoleh dari bahan alami seperti air kelapa. Air kelapa dapat dijadikan sebagai pengganti ZPT karena harganya lebih murah dan dapat diperoleh dengan mudah sehingga lebih efisien dari segi biaya dan waktu. Air kelapa mengandung banyak senyawa organik yaitu 1,3 diphenilurea, zeatin gluoksida, zeatin ribosia, kadar K dan CL tinggi, protein, karbohidrat (Yunita, 2011). Unsur K (kalium) dalam air kelapa yang memiliki kadar yang tinggi dapat merangsang pertumbuhan dengan cepat (Tiwery, 2014). Air kelapa dapat memacu pembentukan tunas karena mengandung hormon auksin dan sitokinin karena dalam 1 liter air kelapa mengandung ZPT kinetin sebesar 273,62 mg. Kandungan hormon tersebut dapat sebagai penstimulir proliferasi pada jaringan guna membantu memperlancar metabolisme serta respirasi (Kristina dan Syahid, 2012). Perlakuan air kelapa tunggal dengan konsentrasi $150 \mathrm{ml} / 1$ dapat memacu pertumbuhan batang eksplan sampai mencapai tinggi dan membentuk akar pada jumlah yang maksimum pada kultur jaringan tanaman anggrek (Djajanegara, 2010). Lebih lanjut Biradar et al. (2016) melaporkan bahwa induksi tunas vanili dipengaruhi oleh penambahan BAP $1 \mathrm{mg} / \mathrm{l}$ dan $1,5 \%$ air kelapa dalam media MS.

Penambahan air kelapa dalam media MS untuk perbanyakan vanili melalui teknik kultur jaringan belum banyak dilaporkan. Oleh karena itu, tujuan dari penelitian ini adalah untuk menganalisis penambahan air kelapa pada media MS terhadap pertumbuhan eksplan vanili secara in vitro.

\section{BAHAN DAN METODE}

Penelitian ini dilaksanakan di Laboratorium Kultur Jaringan Politeknik Negeri Jember pada bulan Februari - Juni 2021. Kegiatan menggunakan analisis Ttest untuk membandingkan perlakuan media dasar MS tanpa penambahan air 
kelapa (P0) dan media dasar MS dengan penambahan air kelapa 15\% (P1). Eksplan berasal dari 1 ruas batang vanili dari tanaman induk vanili in vitro.

\section{Sterilisasi Ruang dan Alat}

Sterilisasi ruang dilakukan dengan melarutkan lysol 10\% menggunakan air untuk mengepel lantai ruang persiapan, ruang inokulasi dan ruang inkubasi. Sterilisasi lanjutan untuk ruang inokulasi dan ruang inkubasi menggunakan formalin $1 \%$ dan menutup kedua ruangan selama 24 jam. Sterilisasi Laminar Air Flow Cabinet menggunakan lampu UV dan alkohol 70\% sebelum digunakan. Sterilisasi peralatan gelas seperti botol kultur, gelas ukur, erlenmeyer, beaker glass, cawan petri disterilkan didalam oven selama 120 menit dan peralatan non gelas seperti dissecting set, tutup botol dan aquadest steril menggunakan autoklaf.

\section{Media Perlakuan}

Media dasar Murashige dan Skoog (MS) terdiri dari nutrisi hara makro, nutrisi hara mikro, vitamin, $100 \mathrm{mg} / \mathrm{l}$ inositol, asam amino, $30 \mathrm{~g} / 1$ sukrosa dan agar-agar 8 $\mathrm{g} / \mathrm{l}$ yang diukur dengan neraca digital serta pipet. Air kelapa yang digunakan berasal dari air buah kelapa yang berumur 7-8 bulan $( \pm 210$ hari). $\mathrm{pH}$ media ditetapkan pada nilai 5,7-5,8 dengan $\mathrm{pH}$ meter. Media yang telah matang dimasukkan kedalam botol kultur dan ditutup dengan penutup plastik kemudian disterilkan dengan autoklaf selama 30 menit. Pemberian label sesuai perlakuan pada botol kultur.

\section{Sterilisasi dan Inokulasi Eksplan}

Sterilisasi LAF sesuai prosedur sebelum melakukan sterilisasi dan inisasi eksplan. Peralatan dissecting set, hand sprayer berisi alkohol 70\%, lampu bunsen, cawan petri dan tissue. Insiasi eksplan dengan memotong tiap ruas batang planlet vanili steril sebagai eksplan dan ditanam pada media sesuai perlakuan.

\section{Inkubasi}

Setiap botol berisi 1 eksplan vanili dan ditempatkan pada ruang inkubasi dengan pengaturan suhu dipertahankan pada $26^{\circ} \mathrm{C} \pm 2^{\circ} \mathrm{C}$ pada kelembaban relatif 60-70\%. Siklus pencahayaan selama 16 jam terang dan 8 jam gelap dengan intensitas cahaya 40,5 mol yang disediakan oleh lampu neon putih (Erawati et al, 2020).

\section{Parameter Pengamatan}

Pengamatan terdiri atas parameter a) Kedinian bertunas (hari) yaitu pengamatan kecepatan bertunas yang dilakukan setiap hari selama 30 hsi dan tunas mulai tumbuh ditandai dengan muncul mata tunas pada eksplan, b) Tinggi tunas $(\mathrm{cm})$ yaitu pengamatan tinggi tunas dilakukan pada akhir pengamatan $8 \mathrm{msi}$ dengan mengukur panjang tunas yang tumbuh pada setiap perlakuan, c) Jumlah akar (akar) yaitu pengamatan jumlah akar yang dilakukan pada $2,4,6$, dan 8 msi dengan menghitung jumlah akar yang tumbuh pada eksplan setiap perlakuan, d) Panjang akar (cm) yaitu pengamatan panjang akar dilakukan pada akhir pengamatan 8 msi dengan mengukur panjang akar yang tumbuh pada eksplan setiap perlakuan.

\section{HASIL DAN PEMBAHASAN Hasil}

Kandungan sukrosa yang dimiliki oleh air kelapa akan memberikan dukungan energi untuk pertumbuhan dan perkembangan jaringan yang dikulturkan. Hasil analisis T-test pada parameter kedinian bertunas, tinggi tunas, jumlah akar dan panjang akar disajikan pada Tabel 1. Sedangkan rerata pengukuran masingmasing parameter terdapat pada Tabel 2. 
Tabel 1. Rangkuman Analisis T-test Parameter Pertumbuhan Eksplan Pada Peran Air Kelapa Terhadap Pertumbuhan Ekplan Kultur Vanili

\begin{tabular}{lcccc}
\hline Parameter Pengamatan & T Hitung & Notasi & T Tabel 5\% & T Tabel 1\% \\
\hline Kedinian Bertunas & 0,671 & $\mathrm{~ns}$ & & \\
Tinggi Tunas & 2,794 & $* *$ & & \\
Jumlah Akar 2 msi & 0,509 & $\mathrm{~ns}$ & & 2,66 \\
Jumlah Akar 4 msi & 1,184 & $\mathrm{~ns}$ & 2,00 & \\
Jumlah Akar 6 msi & 1,472 & $\mathrm{~ns}$ & & \\
Jumlah Akar 8 msi & 2,214 & $*$ & & \\
Panjang Akar & 0,151 & ns & \\
Keterangan: msi = minggu setelah inokulasi, ns $=$ berbeda tidak nyata, ${ }^{*}=$ berbeda nyata, ${ }^{* *}=$ berbeda sangat \\
$\quad$ nyata
\end{tabular}

Tabel 2. Rangkuman Rerata Parameter Pertumbuhan Eksplan Pada Peran Air Kelapa Terhadap Pertumbuhan Ekplan Kultur Vanili

\begin{tabular}{lcccc}
\hline \multirow{2}{*}{ Parameter } & Satuan & Notasi & $\begin{array}{c}\text { Tanpa Penambahan } \\
\text { Air Kelapa }\end{array}$ & $\begin{array}{c}\text { Dengan } \\
\text { Penambahan Air } \\
\text { Kelapa }\end{array}$ \\
\hline Kedinian Bertunas & hari & ns & 23 & 20 \\
Tinggi Tunas & $\mathrm{cm}$ & $* *$ & 2,90 & 4,55 \\
Jumlah Akar 2 msi & akar & ns & 0,50 & 0,56 \\
Jumlah Akar 4 msi & akar & ns & 0,76 & 0,93 \\
Jumlah Akar 6 msi & akar & ns & 1,06 & 1,33 \\
Jumlah Akar 8 msi & akar & $*$ & 1,50 & 2,03 \\
Panjang Akar & $\mathrm{cm}$ & ns & 7,53 & 7,77 \\
\hline Keterangan: msi = minggu setelah inokulasi, ns $=$ berbeda tidak nyata, $*$ berbeda nyata, ** = berbeda sangat \\
nyata
\end{tabular}

\section{Pembahasan}

\section{Kedinian Bertunas}

Berdasarkan analisis statistika Uji-T (Tabel 1), pengamatan kedinian bertunas diamati setiap hari sampai 30 hari setelah tanam (hsi) menunjukkan hasil yang berbeda tidak nyata antara perlakuan tanpa penambahan air kelapa (P0) dan penambahan air kelapa $15 \%$ (P1). Pengamatan ini dilakukan dengan tunas yang muncul ditandai munculnya tonjolan hijau yang terletak di ketiak daun pada ruasnya. Berdasarkan Tabel 2 dapat diketahui bahwa perlakuan tanpa penambahan air kelapa (P0) mulai muncul tunas rerata pada 23 hsi dan untuk perlakuan air kelapa (P1) muncul tunas rerata 20 hsi.
Kedinian bertunas mendapat hasil berbeda tidak nyata dapat disebabkan oleh beberapa faktor seperti jenis eksplan, organ yang digunakan, keadaan eksplan sehingga akan mempengaruhi hasilnya (Lestari, 2011). Hal ini juga sesuai dengan laporan Erawati et al. (2020) bahwa kedinian bertunas tidak dipengaruhi oleh penambahan ZPT karena sudah terdapat mata tunas pada tiap ruas eskplan. Pada saat pengamatan eksplan yang lebih cepat muncul akar dibandingkan dengan tunasnya. Akar tersebut muncul ditandai dengan adanya bintik kecil berwarna putih pada ruas. Pengamatan kedinian bertunas diamati sampai 30 hsi dan berbeda dengan laporan Njoroge et al. (2015) yang menyatakan bahwa kedinian bertunas pada 
ekplan vanili dalam kisaran waktu 2 minggu.

\section{Tinggi Tunas}

Pengamatan tinggi tunas eksplan vanili dilakukan pada umur ekplan 8 minggu setelah tanam (msi). Berdasarkan analisis statistika Uji-T (Tabel 1) menunjukkan hasil berbeda sangat nyata dimana nilai $\mathrm{T}$ hitung lebih besar daripada nilai $\mathrm{T}$ tabel $1 \%$. Rerata tinggi tunas ditampilkan pada Tabel 2 dengan tinggi tunas rerata $2,90 \mathrm{~cm}$ pada perlakuan tanpa penambahan air kelapa dan tinggi tunas rerata $4,55 \mathrm{~cm}$ pada perlakuan dengan penambahan air kelapa. Tinggi tunas di ukur dari pangkal batang sampai titik tumbuh.

Eksplan yang diinokulasikan pada media dasar MS dengan penambahan air kelapa $15 \%$ memiliki tunas yang lebih tinggi dibandingkan dengan eksplan yang ditanam pada media MS tanpa penambahan air kelapa karena pada air kelapa terdapat karbohidrat, vitamin, mineral, dan ZPT seperti auksin, sitokinin, dan giberelin yang berguna sebagai pendorong dalam poliferasi jaringan, memperlancar metabolisme dan respirasi. Dalam air kelapa juga memiliki kandungan vitamin $C$ yang berguna dalam merangsang pertumbuhan batang dimana terjadi proses pembelahan sel, pemanjangan sel, dan pembesaran sel yang baru pada tanaman (Widyastoety, 2003).
Pranata et al. (2015) menyatakan bahwa pemberian air kelapa dengan konsentrasi $15 \%$ dapat menghasilkan tinggi tanaman secara maksimum dengan baik dimana konsentrasi air kelapa sebagai ZPT ini dapat mempengaruhi tinggi tunas pada eksplan karena memiliki kandungan unsur hara yang berfungsi membantu pertumbuhan dan perkembangan jaringan sehingga sel akan mengalami differensiasi. Hal ini selaras dengan Mustakim (2015) yang menyatakan pemberian air kelapa dengan konsentrasi $15 \%$ dapat memberikan hasil yang baik dalam pembentukan jumlah daun, jumlah akar, tinggi eksplan dan berat eksplan. Hasil yang sama juga pada media MS yang di modifikasi dengan tambahan air kelapa mendapat hasil berpengaruh nyata pada tinggi tunas tanaman subkultur anggrek Cymbidium pada umur 56 hsi karena adanya pengaruh hormon eksogen dalam air kelapa (Pratama, 2018).

\section{Jumlah Akar}

Pengamatan jumlah akar kultur jaringan tanaman vanili dilakukan pada 2 , 4, 6, dan 8 msi. Berdasarkan Tabel 1 diketahui bahwa jumlah akar dipengaruhi oleh penambahan air kelapa $15 \%$ hanya pada 8 msi saja, sedangkan rentang waktu pengamatan 2, 4, 6 msi berbeda tidak nyata antar perlakuan. Meskipun demikian, jumlah akar terus bertambah sesuai pertambahan waktu dengan rerata yang tertera pada Tabel 2. 


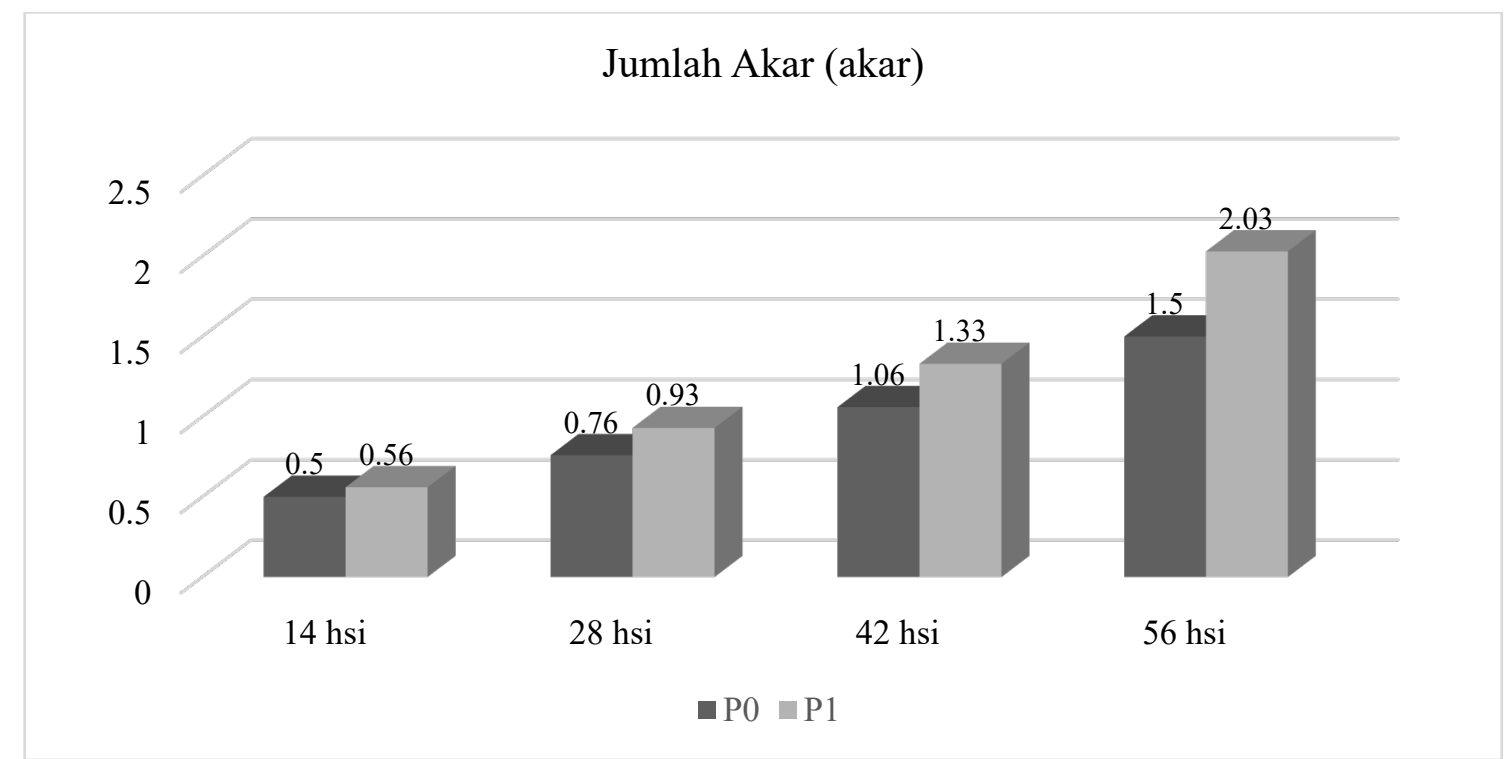

Gambar 1. Rerata Jumlah Akar Eksplan Vanili Pada Penambahan Air Kelapa Terhadap Pertumbuhan Eksplan Kultur Vanili

Terbentuknya akar saat eksplan setelah membentuk tunas yang dipacu oleh auksin dan sitokonin pada jaringan eksplan tersebut. Salah satu komponen vitamin yang terdapat dalam media MS adalah kandungan Tiamin yang berguna dalam mempercepat pembelahan meristem akar dibantu oleh koenzim yang terdapat dalam reaksi dan menghasilkan energi serta karbohidrat (Agriani, 2010). Hal tersebut menjelaskan mengapa hasil analisis jumlah akar pada 2, 4 dan 6 msi berbeda tidak nyata berdasarkan analisis T-test. Munculnya akar ditandai dengan adanya bintik kecil berwarna putih dengan bulu bulu halus. Akar ini letaknya berada di bagian bawah eksplan dan tumbuh di setiap ruas pada eksplan.

Berdasarkan Gambar 1 untuk grafik jumlah akar pada saat eksplan berumur 8 msi terjadi interaksi antara media MS dan pemberian air kelapa terhadap jumlah akar pada inokulasi vanili secara in vitro dengan rerata 2,03 akar setiap eksplan untuk P1 dan pada P0 sebanyak 1,50 akar setiap eksplan. Air kelapa merupakan ZPT yang mengandung sitokinin dan auksin yang dapat berperan dalam proses morfogenesis tanaman yang memacu pembentukan akar dan tunas apabila dalam media mengandung zat sitokinin dan auksin yang seimbang (Inayah, 2016). Menurut Tiwery (2014) pada air kelapa mengandung unsur Kalium (K) yang dapat merangsang pertumbuhan dengan cepat. Ekplan yang memiliki kualitas akar yang baik akan memiliki tingkat keberhasilan pada tahap aklimatisasi. Sehingga dibutuhkan formulasi media tanam yang tepat untuk menunjang hal tersebut terlebih lagi terhadap tanaman vanili dimana pembetukan akarnya cukup sulit.

\section{Panjang Akar}

Pengamatan panjang akar eksplan vanili dilakukan pada 8 msi. Berdasarkan analisis statistika Uji-T pada tabel 1 menunjukkan hasil yang berbeda tidak nyata antara perlakuan P0 dengan perlakuan $\mathrm{P} 1$ dimana nilai $\mathrm{T}$ hitung lebih kecil daripada nilai $\mathrm{T}$ tabel. Berdasarkan Tabel 2 dapat diketahui rerata panjang akar pada perlakuan tanpa penambahan air kelapa sebesar $7,53 \mathrm{~cm}$ dan perlakuan penambahan air kelapa mempunyai rerata panjang akar $7,7 \mathrm{~cm}$. 


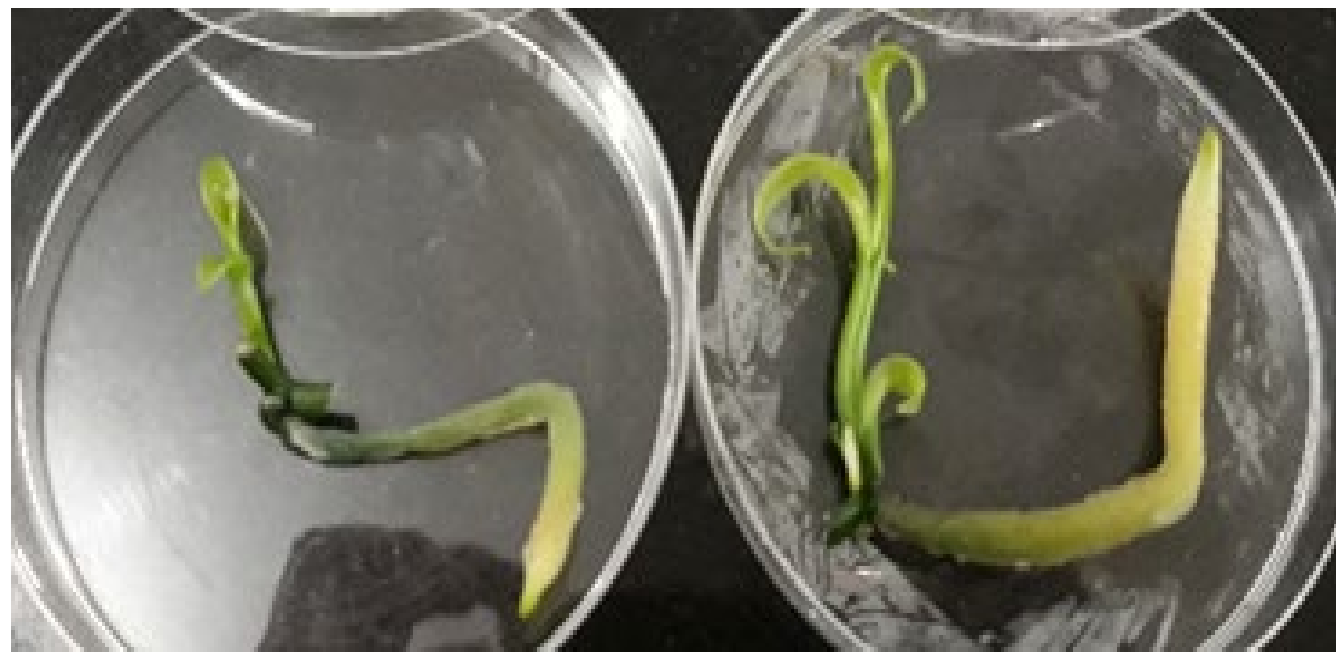

Gambar 2. Pertumbuhan panjang akar pada umur eksplan 8 msi (A) Panjang akar pada perlakuan tanpa penambahan air kelapa, (B) Panjang akar pada perlakuan dengan penambahan air kelapa

Gambar 2 memperlihatkan pertumbuhan panjang akar pada perlakuan P0 (Gambar 2A) dan perlakuan P1 (Gambar 2B). Meskipun hasil uji $\mathrm{T}$ memperlihatkan hasil yang berbeda tidak nyata tetapi eksplan yang ditanam pada media dengan pemberian air kelapa $15 \%$ memiliki akar lebih panjang dibandingkan dengan tanpa penambahan air kelapa. Auksin yang terkandung dalam air kelapa berfungsi dalam inisiasi dan pemanjangan akar sehingga eksplan yang tidak mendapat tambahan auksin cenderung lebih pendek pertambahan panjang akarnya (Hidayat dan Hariadi, 2015).

\section{KESIMPULAN}

1) Penambahan air kelapa $15 \%$ mempengaruhi tinggi tunas eksplan vanili dengan rerata $4,45 \mathrm{~cm} / \mathrm{eksplan}$ dan jumlah akar dengan rerata 2,03 akar/eksplan pada umur eksplan 56 hsi,

2) Penambahan air kelapa $15 \%$ memiliki pengaruh yang sama dengan tanpa penambahan air kelapa terhadap kedinian bertunas, jumlah akar pada 14 , 28, 42 hsi dan panjang akar eksplan vanili,
3) Penambahan air kelapa 15\% mampu mendukung pertumbuhan panjang tunas dan akar tetapi tidak mampu menggandakan tunas eksplan vanili.

\section{DAFTAR PUSTAKA}

Anggriani. (2010). Tehnik Perbanyakan Secara Kultur Jaringan. Pustaka Abadi Yogyakarta. Djajanegara. (2010). Pemanfaatan Limbah Buah Pisang dan Air Kelapa Sebagai Bahan Media Kultur Jaringan Anggrek Bulan (Plalaenopsis amabilis) tipe 229.

Biradar, V., Inamdar, A., Shamse, A., \& Patil, M. S. (2016). In vitro Studies on the Influence of Different Concentrations of Growth Regulators on Economically Important Orchid, Vanilla planifolia. Int. J. Curr. Microbiol. Appl. Sci, 5(9), 311-323.

Erawati, D. N., Fisdiana, U., \& Kadafi, M. (2020). Respon Eksplan Vanili (Vanilli planifolia) dengan Stimulasi BAP dan NAA Melalui Teknik Mikropropagasi. Jurnal Agriprima, 4(2)146-153.

Erawati, D. N., Wardati, I., Humaidah, S., \& Fisdiana, U. (2020). Micropropagation of Vanilla (Vanilla planifolia Andrews) with 
Modification of Cytokinins. IOP Conference Series: Earth and Environmental Science, 411(1),12009.

Erona, M. (2016). Pertumbuhan Bibit Vanili (Vanilla planifolia A.) Terinokulasi Fungi Mikoriza Arbuskula dan Trichoderma harzianum Pada Tanah Ultisol. Program Pascasarjana Institut Pertanian Bogor.

Hidayat AY dan Hariyadi. (2015). Respon Pertumbuhan Bibit Panili (Vanilla planifolia Andrews) terhadap Aplikasi Zat Pengatur Tumbuh dan Pupuk Cair NPK. Bul. Agrohorti 3(1): 39-46.

Inayah, M. (2016). Pemberian Air Kelapa dan Ekstrak Pisang Raja Terhadap Kecambahan Biji dan Perkembangan Tunas Embrio Anggrek Dendrobium Lasianthera. Universitas Airlangga, Surabaya.

Kartika, A., R. Rosman. (2018). Sirkuler Informasi Teknologi Tanaman Rempah dan Obat Budidaya Vanili. Bogor: Balai Penelitian Tanaman Rempah dan Obat.

Kristina dan Syahid. (2012). Penelitian Kultur Jaringan Temulawak. Universitas Negeri Padang, Padang.

Lestari, E. G. (2011). Peranan Zat Pengatur Tumbuh Dalam Perbanyakan Tanaan Melalui Kultur Jaringan. Jurnal AgroBiogen, 7(1).

Loedji, H. (2019). 8 Besar Produk Pertanian Indonesia. https://www.portonews.com/2019/pe rnik-bisnis/8-besar-produk-pertanianindonesia/. [13 September 2020].

Nasution, S. S. (2013). Pengaruh Teknik Sterilisasi Terhadap Keberhasilan Inisiasi Eksplan Paulownia (Paulownia elongata Sy. Hu) Secara In Vitro. Program Pasca Sarjana Intitut Pertanian Bogor, Bogor.

Njoroge, A. M., Gitonga, L., Mutuma, E., Mimano, L., Macharia, C., Wasilwa,
LMungai, A. (2005). Propagation of high quality planting materials of Vanilla (Vanilla planifolia) through tissue culture. Kenya Agricultural Research Institute (KARI), Thika National Agricultural Research Laboratories Nairobi.Kenya, 1-4.

Mustakim, B. F. Wahidahl, A. Al-Fauzy. (2015). Pengaruh Penambahan Air Kelapa Terhadap Pertumbuhan Stek Mikro Tanaman Krisan (Chrusanthemum indicium) Secara In Vitro. UIN Alauddin, Makassar.

Pranata, M. G., A. Yunus dan B. Pujiasmanto. (2015). Pengaruh Konsentrasi NAA dan Air Kelapa Terhadap Multiplikasi Temulawak (Curcuma Xanthorrizha roxb) Secara In Vitro. UNS: Journal of Sustainable Agriculture, 30(2).

Pratama, J. (2018). Modifikasi Media MS dengan Penambahan Air Kelapa Untuk Subkultur I Anggrek Cymbidium. Jurnal Agrium, 15(2), 91-109.

Tiwery, RR. (2014). Pengaruh Penggunaan Air Kelapa (Cocos nucifera) Terhadap Pertumbuhan Tanaman Sawi (Brassica juncea L.). Biopendix, 1(1), 86-94.

Wiraatmaja, I, W. (2017). Zat Pengatur Tumbuh Auksin dan Cara Penggunaannya dalam Bidang Pertanian. Fakultas Pertanian Universitas Udayana, Bali.

Widiastoety, D dan Purbadi. (2003). Pengaruh Bubur Ubi Kayu dan Ubi Jalar Terhadap Pertumbuhan Plantlet Anggrek Dendrobium. Jurnal Hortikultural, 13(1), 1-6.

Yunita, R. (2011). Pengaruh Pemberian Urine Sapi, Air Kelapa, dan RootoneF Terhadap Pertumbuhan Setek Tanaman Markisa (Passiflora edulis va. Flavicarpa). Fakultas Pertanian Universitas Andalas, Padang.

Zulkarnain, H. (2011). Kultur Jaringan Tanaman, Solusi Perbanyakan 
Tanaman Budidaya. Bumi Aksara, Jakarta.

Bryszak, M., Gao, M., Kolodziejski, P., Stochmal, A., Slusarczyk, S., Patra, A. K., \& Cieslak, A. (2018). Coleus amboinicus (Lour.) leaves as a modulator of ruminal methanogenesis and biohydrogenation in vitro. Journal of Animal Science. https://doi.org/10.1093/jas/sky321

Yu, S.-F., Chen, T.-M., \& Chen, Y.-H. (2007). Apoptosis and Necrosis are Involved in the Toxicity of Sauropus androgynus in an In Vitro Study. Journal of the Formosan Medical Association, 106(7), 537-547. https://doi.org/10.1016/S09296646(07)60004-7

Zhang, B., Wijesundara, N. M., Abbey, Lord, \& Rupasinghe, H. P. V. (2017). Growing medium amendments effect on growth, secondary metabolites and anti-streptococcal activity of two species of Plectranthus. Journal of Applied Research on Medicinal and Aromatic Plants, 5, 53-59. https://doi.org/10.1016/j.jarmap.201 6.11 .001 